\title{
Må samarbeide mer på
} tvers

Tradisjonelt har ulike profesjoner arbeidet parallelt. Framo ver er det helt nødvendig å samarbeide på tvers for å møte bemanningsbehovet og gi ef fektiv helsehjelp.

\section{Forfattere}

\author{
Bente Kvilhaugsvik \\ Høgskolelektor \\ Høgskolen Stord/Haugesund \\ Gjertrud Husøy \\ Førstelektor \\ Høgskolen Stord, Haugesund
}

\section{Nøkkelord}

\begin{tabular}{l|l|l|} 
Rehabilitering Tverrprofesjonell samarbeidslæring Teamarbeid & Th
\end{tabular}

Sykepleien 2017 105(3)(64-67)

DOI: https://doi.org/10.4220/Sykepleiens.2017.60913

\section{HOVEDBUDSKAP}

I årene framover vil det være mange personer med sammensatte behov, men færre som kan yte helsehjelp. Samtidig vil den $\emptyset$ kende spesialiseringen i helsetjenesten innebære en risiko for fragmentering av tjenester. Profesjonene må samarbeide for både å møte bemanningsproblemet og gi kontinuitet i tjenestetilbudet. 
I helsetjenesten har det vært tradisjon at ulike profesjoner har samarbeidet. Likevel har Verdens helseorganisasjon (WHO) lenge hatt oppmerksomheten rettet mot å styrke tverrfaglig samarbeid. Den har også vært opptatt av at studenter fra helsefaglige profesjoner må lære å samarbeide på tvers av profesjonsgrensene i løpet av utdanningen.

Ved å forbedre det tverrprofesjonelle samarbeidet i praksis og utdanning, kan man møte bemanningsproblemet som kommer i helsetjenesten $\mathrm{i}$ mange land (1). Behovene for forbedrete samarbeidsrutiner mellom profesjoner, avdelinger og nivåer i helsetjenesten har dessuten sammenheng med $ø$ kende spesialisering. Pasientene tilbys avansert behandling i enheter som kan være plassert langt fra hverandre fysisk.

Når tjenester ikke kommuniserer godt nok med hverandre, oppstår det lett misforståelser, forsinkelser og diskontinuitet i tjenestetilbudet. For å unngå at effekten av behandlingen skal avta i forbindelse med utskriving fra sykehus til kommunehelsetjenesten, må ofte flere profesjoner som lege, sykepleier og fysioterapeut følge opp pasientene. Dersom man da ikke klarer å etablere godt nok samarbeid på tvers av profesjoner og nivåer, er det fare for at intervensjoner ikke får ønsket effekt, og for at pasienter må reinnlegges (2).

\section{Folkets behov må møtes}

Folkehelsen i en region påvirkes av utdanningsnivået til helsepersonellet. Forskning, utdanning og helsetjenester må derfor samsvare med regionale og nasjonale prioriteringer, sier Fleet og medarbeidere (3). Helsepersonell må tilbys utdanning og videreutdanning som bygger på befolkningens behov. Hall (4) sier at de ulike profesjonene hviler på forskjellig kultur- og verdigrunnlag fordi de er utviklet i ulike historiske og kulturelle kontekster. 


\section{三 «Selv om man ser på det samme, ser man ulike ting.»}

Profesjonene bygger på ulike kunnskapstradisjoner og ser derfor forskjellig på problemer de presenteres overfor. Selv om man ser på det samme, ser man ulike ting. Studentene overtar profesjonenes kunnskapssyn og verdier, og derfor opprettholdes skillene mellom dem. Likedan videreføres verdisyn, kunnskapssyn, språk og strategier for problemløsing, som inkluderer profesjonens håndheving av ansvar og kontroll.

I Norge er det tilrettelagt for koordinering og tverrprofesjonell samhandling samt implementering av hjemmerehabilitering, med føringer i lovverker, forskrifter og stortingsmeldinger (5). Kommuner og helseforetak trenger å utvikle praktiske samarbeidsrutiner på tvers av nivåer, der koordinerende enhet for rehabilitering og tverrfaglige team inkluderes.

\section{Samarbeidslæring på tvers}

Aktuelle samarbeidsparter i team bestemmes på bakgrunn av kompetanse sett i forhold til målet. WHO (1) påpeker at ikke alle teammedlemmene trenger å være helsepersonell, men profesjonene må ha samarbeidskompetanse og vite hvordan teamarbeid kan optimalisere effekten av teammedlemmenes samlete innsats.

Når studenter fra helse- og sosialfaglige profesjoner lærer å samarbeide tverrprofesjonelt, kalles det «tverrprofesjonell samarbeidslæring» (1), som i Norge forkortes til TPS. Tverrprofesjonell kunnskap og kompetanse, både innen samarbeid og TPS, handler om relasjoner, strukturer i tjenestene og samspill på person-, organisasjons- og ledelsesnivå (7). 
Både ansatte og studenter trenger å lære tverrprofesjonelt samarbeid. Når teamarbeidet fungerer godt, er praksis en naturlig læringsarena. Hvis helsepersonellet ikke er trent i teamarbeid, er det behov for tverrprofesjonell samarbeidslæring også for ferdig utdannete.

\section{Hensikt med studien}

Målet med studien var å belyse hvordan helsepersonell i rehabilitering på ulike nivåer i helsetjenesten definerer tverrprofesjonelt samarbeid. Vi ønsket også å finne ut hvordan de opplevde at samarbeidet fungerte i praksis. Videre ønsket vi å finne ut hvilke læringsmuligheter studentene har til å lære samarbeid på tvers av profesjoner, avdelinger og nivåer, både på ulike sengeposter og i hjemmetjenesten i forbindelse med praksisperioder.

Både kommunehelsetjenesten og spesialisthelsetjenesten har ansvar i forbindelse med rehabilitering. Spesialisthelsetjenesten har ansvar for den spesialiserte rehabiliteringen, og kommunene har ansvar for mindre spesialisert rehabilitering. Både i spesialist- og kommunehelsetjenesten er det behov for samarbeid på tvers av profesjoner og nivåer for å gi kontinuitet i behandlingsforløpet. Samtidig er avdelinger i sykehus og kommuner praksisarena for studenter i helsefaglige utdanninger.

Ut fra dette valgte vi å samle inn data ved hjelp av tre fokusgrupper, der alle fikk de samme spørsmålene. Den første gruppen av informanter var fra et tverrprofesjonelt team i en spesialisert rehabiliteringsavdeling i sykehus. En annen gruppe var samarbeidsparter i en kommune som har implementert hjemmerehabilitering. Den tredje gruppen var praksislærere for sykepleierstudenter.

\section{Nye ord, samme innhold}


Fokusgruppen med praksislærere i sykepleie var opptatt av å definere begrepene «tverrfaglig» versus «tverrprofesjonell» og «brukermedvirkning». På 1980tallet snakket man mye om tverrfaglig samarbeid. Praksislærerne anså begrepet «tverrprofesjonell» som et nyere begrep, der oppmerksomheten på den profesjonsspesifikke kompetansen styrkes. De var kritiske til at det innarbeidete begrepet «tverrfaglig» var byttet ut, og lurte på om endringen var symbol på «det moderne menneskets fikenblad - at det nesten er det samme, men med nye ord», som en av praksislærerne sa.

Informantene mente at det ligger i begrepet «tverrprofesjonelt» at profesjonene møtes, arbeider sammen og supplerer hverandres kunnskap og kompetanse med mål om å ivareta et helhetlig helsetjenestetilbud til pasientene: «Og så lager de seg et samarbeid ut fra det.» Ifølge Meld. St. 13 (20112013) må profesjonene bli dyktige ved å samarbeide seg imellom, lytte til pasientenes synspunkter og informere og veilede (6).

Fokusgruppene diskuterte kravet til brukermedvirkning opp mot situasjoner der helsepersonell må ta avgjørelser på vegne av pasienter. Praksislærerne mente det kan være en hårfin balanse mellom pasientens selvbestemmelse og profesjonenes kunnskap om helseproblemet.

\section{Brukte egen erfaring}

Det å kunne beskrive egen og andre profesjoners kompetanse er en delferdighet i tverrprofesjonell samarbeidskompetanse (7). Mange informanter i de tre fokusgruppene hadde arbeidet både parallelt og tverrprofesjonelt. En av fysioterapeutene beskrev hvordan hun lærte å se sin egen profesjonskompetanse opp mot andres: 
«Jeg lærer også at en del av de tingene jeg har i

ryggmargen nå, fordi jeg har vært fysioterapeut i 30 år, det går plutselig opp for meg at det har ikke de andre i ryggmargen. Jeg trodde det var medfødt, men det er det bare ikke. Så du kan si at jeg lærer om meg selv, og jeg lærer av dem, og jeg lærer av hva jeg ikke kan.»

\section{三 «Så du kan si at jeg lærer om meg selv, og jeg lærer av dem, og jeg lærer av hva jeg ikke kan.»}

\section{Fysioterapeut}

Universitets- og høgskolerådet (8) sier at tverrprofesjonell samarbeidskompetanse er når delkompetansene blir integrert og studentene samarbeider tverrprofesjonelt i praktiske situasjoner. En av praksislærerne i sykepleie uttrykte det på denne måten:

«For meg da, handler det tverrprofesjonelle samarbeidet om at jeg kommer med min kompetanse, du kommer med din, og sammen ser vi helheten. Altså blir det sånn som et puslespill som skal bli et godt hjelpetilbud for pasientene.»

\section{Utvikling av team}

Alle fokusgruppene poengterte at følgende momenter var viktige i teamarbeid:

- evne til kommunikasjon

- evne til etisk refleksjon og konflikthåndtering

- kjennskap til egen og andre profesjoners kompetanse og kultur, ledelse og organisering

- kunnskap om utfordringer som kan oppstå ved komplekse sykdomstilstander, individuell plan og sammenhengende tjenester 
Da teamsamarbeid skulle etableres, var disse faktorene viktige å ta hensyn til. De ulike fokusgruppene mente at profesjonene tradisjonelt har jobbet parallelt, med tette skott mellom ansvarsområder. Man risikerer å «jobbe fra hverandre», eller at profesjonene konkurrerer i stedet for å samarbeide. Dette kan ha å gjøre med at profesjonene posisjonerer seg i forhold til hverandre, eller ikke vet hva andre kan bringe inn i teamarbeidet.

Hall (4) sier at profesjonenes tenkning og holdninger arves gjennom generasjoner og videreføres når studentene sosialiseres inn i profesjonen. Dersom tverrprofesjonell samarbeidskompetanse skal være en del av den profesjonelle yrkesrollen, må studentene sosialiseres inn i rollene som teammedlemmer. Når dette skjer tidlig i utdanningen, bygges det i stedet en bro mellom profesjonene.

Teamarbeid i helsetjenestene er likevel ikke nytt. Noen informanter hadde erfaring med oppbygging og «reparasjon» av team. Enkelte ganger må konflikter løses før man kan etablere en felles forståelse som utgangspunkt for teamarbeid. En praksislærer i sykepleie gir et eksempel på en kilde til misforståelse og konflikt:

«Når jeg sa noe om en diagnose eller symptomer, ble det forstått på vidt forskjellige måter. På en helt annen måte enn hvis jeg hadde sagt det til en gruppe der alle hadde sykepleierutdanning i bunnen. Det hadde vært enklere. Men kanskje ikke nødvendigvis så spennende.»

Eksempelet belyser behovet for at teammedlemmene må lytte til hverandre. Teammedlemmene må forsøke å forstå informasjon på tilnærmet samme måte og arbeide for konsensus. Når hvert teammedlem får arbeide «på egen godfot» med oppmerksomheten rettet mot pasienten, mente lærerne at risikoen for maktkamp ble redusert. 


\section{Fra ulike planeter}

Det tverrprofesjonelle teamet i hjemmerehabilitering i kommunen var nyetablert. Dette «teamet består av tre helt forskjellige personer. Vi er fra tre forskjellige planeter», sa en av informantene. Teammedlemmene hadde ulik profesjon, alder og utdanning fra ulik tidsperiode. De hadde en genuin interesse for samarbeidet og jobbet aktivt med å utvikle tverrprofesjonell kommunikasjon: «Vi prøver å spille oss sammen, slik at vi snakker litt på samme måten.»

\section{«Vi prøver å spille oss sammen, slik at vi snakker litt på samme måten.»}

\section{Ansatt i hjemmerehabiliteringen}

Innkomstsamtalene ble gjennomført likt uansett om det var fysioterapeut, ergoterapeut eller sykepleier som gjennomførte samtalen. Teammedlemmene lærte mye av hverandre og ga hverandre tilbakemelding på kommunikasjon og testing.

Willumsen (9) sier at tverrprofesjonelt samarbeid kjennetegnes av at profesjonene arbeider tett sammen. De utvikler felles forståelse ved å integrere faggruppenes kunnskap. De beveger seg som team og ikke kun som enkeltprofesjoner. Kommunikasjon i team kan høres enkelt ut, men er ekstremt vanskelig å få til i praksis. For informantene i kommunen var det en påbegynt prosess å jobbe tett sammen.

På den andre siden mente informantene i sykehusets rehabiliteringsavdeling at det ikke var noe spesielt med tverrprofesjonell kommunikasjon sammenliknet med annen kommunikasjon. De hadde god trening i teamarbeid med pasientenes mål i sentrum.

\section{Trivsel styrker teamet}


Informantene både i kommunen og sykehuset anså motivasjon som spesielt viktig. De mente at trivsel og motivasjon virker gjensidig inn på hverandre, og styrker teamets effektivitet. En forutsetning for godt teamsamarbeid er ifølge Interprofessional Education and Collaborative Expert Panel (7) at teammedlemmene kan stole på hverandre. De ulike informantene mente at det er stor forskjell på hvor tett man samarbeider i helsetjenesten.

Praksislærerne i sykepleie hadde erfaring fra samarbeid i og mellom avdelinger og nivåer og med oppfølging av sykepleierstudenter i praksisstudier. Noen av dem hadde pasient- og pårørendeerfaring med krav til teamarbeid og individuell plan. Lærerne mente at profesjonene fortsatt samarbeidet mest med egen profesjon. Informantene i kommunen, derimot, mente at profesjonene arbeidet parallelt, som vil si ved siden av hverandre.

En informant i kommunen sa følgende: «I teamet - det er vel første gang jeg føler at vi prøver veldig sterkt å jobbe tverrprofesjonelt.» Teammedlemmene hadde arbeidet bevisst med teamutvikling i en periode, og stolte på hverandre. Ledelsen og andre ansatte i kommunale tjenester forventet at profesjonene skulle møte brukerne som medlemmer i hjemmerehabiliteringsteamet, og at de skulle utforme rehabiliteringsplaner sammen.

\section{Praksisnært teamarbeid}


I sykehusets rehabiliteringsavdeling hadde

profesjonene ansvar for å kartlegge og komme med forslag til tiltak på hver sine områder. De ulike profesjonenes kartlegginger ble sammenstilt i en tverrprofesjonell funksjonskartlegging. Pasientdata og funksjonsmålinger ble diskutert og vurdert $\mathrm{i}$ tverrprofesjonelle møter. Teamet var opptatt av pasientenes mål og dialog med kommunene om utskriving. Videre var de opptatt av at alle faggruppene kom med sine bidrag, og at nødvendig informasjon til enhver tid var tilgjengelig.

Når målet for rehabiliteringen skulle bestemmes, var pasienten til stede. «Sånn at pasienten ser på, om det skal være armen, eller beina», sa en sykepleier fra sykehusets rehabiliteringsavdeling. Pasientene fikk en koordinator i tillegg til en kontakt fra hver profesjon, som sørget for kontinuitet i rehabiliteringen.

Informantene har det Willumsen (9) beskriver som en praksisnær framstilling av teamarbeid, der brukermedvirkning, organisering, praktisk samarbeid og utskriving står sentralt. Dette er også hva samhandlingsreformen (2), WHO (1) og Interprofessional Education and Collaborative Expert Panel (7) har som mål, nemlig at helsepersonell skal ha fokus på helhetlig, brukerorientert og kvalitetssikret pasientbehandling.

\section{Funksjonskartlegging}

I forbindelse med intensiv kartlegging med funksjonsmålinger og rehabiliteringstiltak i spesialisthelsetjenesten ble utskriving til kommunen nøye planlagt. Noen ganger var det behov for å vise konkrete prosedyrer til personell i kommunen. De ble da invitert til nettverksmøte før utskriving. 
Sykehusets teammedlemmer skrev tverrfaglig rapport med informasjon om funksjonsnivået ved innkomst, vektlegging i rehabiliteringen, funksjon ved utskriving, kontakt med kommunen og forslag til videre tiltak. Eksempel kan være gangtrening, språkopplæring, påkledning og andre daglige aktiviteter. Pasientenes pårørende ble sett på som viktige samarbeidsparter og ble tatt med på nettverksmøter.

\section{La vekt på praksis}

Praksis er ifølge Meld. St. 13 (2011-2012) en viktig arena for tverrprofesjonell samarbeidslæring (6). Teamet i sykehuset hadde ansvar for studenter i praksis, og studentene ble inkludert i teamarbeidet. De la vekt på at studentene skulle se pasientforløpet. «Kanskje er pasienten hjemme på permisjon, ikke sant, så de [studentene] får et annet innblikk i hvordan ting fungerer enn om bare en pasient skal skrives ut. Så får de [studentene] høre med pasienten om hvordan det har fungert hjemme, òg», sa en sykepleier i sykehusets rehabiliteringsavdeling.

Cirka en uke etter utskriving til hjemmet gjennomfører kommunen en ny tverrfaglig vurdering og funksjonskartlegging med «Canadian Occupational Performance Measure», forkortet til COPM (10), der brukeren støttes til å formulere rehabiliteringsmål. Målet med rehabiliteringen var at pasienten skulle ha evne til å ivareta egne aktiviteter i dagliglivet og delta i sosiale sammenhenger.

Fysioterapeut, ergoterapeut og sykepleier i rehabiliteringsteamet brukte sin kompetanse i synergi. De samarbeidet med fastlege, hjemmesykepleie, tjenestekontor og andre for å ivareta en helhetlig oppfølging. Sykepleierstudenter kunne få være med teamet et par dager når de hadde praksis i kommunen.

\section{Mye organisering}


Etter at samhandlingsreformen (2) ble innført, har mye ansvar blitt overført til kommunene. Denne endringen stiller krav til samarbeidskompetanse for profesjoner og institusjoner (11). Det handler mye om organisering og fordeling av oppgaver. «Vet du, da er vi tilbake til det som jeg alltid har tenkt, eller lært, og det er at rehabilitering er 50 prosent organisering og 50 prosent fag», sa en av sykepleierne fra den kommunale rehabiliteringsavdelingen.

Rehabiliteringsavdelingen på sykehuset hadde høyere bemanning sammenliknet med andre sykehusavdelinger, og det tverrprofesjonelle teamet og pasienten var lokalisert på samme sted. Arbeidet med rehabilitering var organisert slik at hver profesjon hadde hovedansvar for profesjonsspesifikke arbeidsoppgaver i kombinasjon med systematisk tverrprofesjonell møtevirksomhet.

Hvert møte hadde et spesifikt formål, der optimal bruk av de samlete ressursene var overordnet. Viktig informasjon var lett tilgjengelig: «Og så har vi en tavle på vaktrommet vårt, der vi skriver navnet på pasienten, og skriver alle kontaktene. Hvilken lege de har, hvilken ergoterapeut og hvilken fysioterapeut, og hvem som er koordinator.»

\section{Krevende i kommunen}

I kommunen var det mer krevende å få teamsamarbeidet på plass, både fordi saksbehandler, rehabiliteringsteam og hjemmetjenesten var plassert i ulike bygninger. I tillegg var de ansatte sosialisert inn i profesjonene uten tverrprofesjonell samarbeidslæring. Det er vanskelig å endre verdier og arbeidsmåter man er sosialisert inn i, ifølge Hall (4).

\section{三 «I kommunen var det mer krevende å få teamsamarbeidet på plass.»}


For å endre organisasjonen måtte de arbeide aktivt for at flere skulle verdsette tverrprofesjonell samarbeidskompetanse. I tillegg måtte de arbeide med samarbeidsstrukturer på tvers av avdelinger $\mathrm{i}$ kommunen, og mellom kommune og spesialisthelsetjeneste. Steinhaug og medarbeidere (5) så behov for å endre tjenestene som system for å forbedre informasjonsutveksling, koordinering og samarbeid.

\section{Tilbød videreutdanning}

Når behovene i befolkningen endres, må helsepersonellet i regionen tilegne seg kompetansen som skal til for å ivareta nye behov for helsehjelp (3). I regionen informantene kom fra, hadde de hatt et prosjekt med hjemmerehabilitering for å ivareta føringene i samhandlingsreformen (2). Høgskolen Stord/Haugesund tilbød videreutdanning i rehabilitering, som ansatte i kommunen kunne søke på. De ansatte fikk også tilbud om tverrprofesjonelt samarbeid, og de som hadde samarbeidskompetanse, lærte andre i organisasjonen ved å være rollemodeller.

I et større utviklingsprosjekt (12) gikk de gjennom organisasjonene for å legge til rette for rehabilitering på tvers av nivåer i helsetjenesten. En ergoterapeut ble ansatt som saksbehandler for rehabiliteringssaker, og fysioterapeut, ergoterapeut og sykepleier ble ansatt i et nytt hjemmerehabiliteringsteam. Når pasientene ble skrevet ut fra sykehus, kunne de søke kommunens tjenestekontor om hjemmerehabilitering.

Dersom brukeren skulle ha hjemmesykepleie samtidig med rehabilitering, formulerte avdelingslederen i hjemmesykepleien oppdraget på arbeidsplanleggeren, slik at alle skulle arbeide på samme måte.

Hjemmerehabilitering ble da satt systematisk på agendaen i organisasjonene.

\section{Konklusjon}


Informantene i studien har erfaring med å samarbeide med ulike fagpersoner og er bevisste på at de må arbeide systematisk på flere nivåer for at et slikt samarbeid skal være mulig. Temaene som belyses i fokusgruppene, samsvarer godt med nasjonale og internasjonale føringer om at tverrprofesjonelt samarbeid handler om å ivareta pasientbrukerkompetansen ved å benytte den profesjonsspesifikke kompetansen optimalt og bruke den i synergi med kompletterende kompetanser for å støtte og hjelpe pasienten eller brukeren.

Organisasjonene i helsetjenesten må gjennomgås av ledelsen i organisasjonene for å sikre strukturer som støtter samarbeid. I denne artikkelen har vi beskrevet eksempler på tverrprofesjonelt samarbeid. Hvordan tverrprofesjonell samarbeidslæring for studenter i helsefaglig profesjonsutdanning konkret kan foregå i praksis, er et stort tema som bør belyses nærmere.

\section{Referanser}

1. Verdens helseorganisasjon (WHO). Framework for action on interprofessional education and collaborative practice. Health Professions Networks Nursing \& Midwifery Human Resourses for Health. 2010. Tilgjengelig fra: http://apps.who.int/iris/bitstream/10665/70185/1/WHO_HRH_HPN_10.3_eng.pdf. (Nedlastet 25.09.2015).

2. $\quad$ Meld. St. 47 (2008-2009).

Samhandlingsreformen. Rett behandling - på rett sted - til rett tid. Oslo: Helse- og omsorgsdepartementet.

3. Fleet LJ, Kirby F, Cutler S, Dunikowski L, Nasmith L, Shaughnessy R. Continuing professional development and social accountability: A review of the literature. Journal of Interprofessional Care 2008;22(S1):15-29.

4. Hall P. Interprofessional teamwork:

Professional cultures as barriers. Journal of Interprofessional Care Supplement 2005;1:188-96. 
5. Steinhaug, S, Lippestad JW, Isaksen H, Werner

A. Rehabilitation in practice. Development of a model for organisation of and cooperation on home-based rehabilitation - an action research project. Disabil Rehabil 2014;36(7):608-16.

6. Meld. St. 13 (2011-2012). Utdanning for velferd. Samspill i praksis. Oslo:

Kunnskapsdepartementet.

7. Interprofessional Education Collaborative

Expert Panel: Core competencies for interprofessional collaborative practice. Report of an expert panel.

Washington, D.C.: Interprofessional Education

Collaborative. 2011. Tilgjengelig fra:

http://www.aacn.nche.edu/educationresources/ipecreport.pdf. (Nedlastet 20.06.2016).

8. Universitets- og høgskolerådet (UHR): Felles innhold i de helse- og sosialfaglige profesjonsutdanningene. 2015. Tilgjengelig fra: http://www.uhr.no/documents/ferdig_rapport_Felles_innhold_290515_1500.pdf. (Nedlastet 18.08.2015). (Nedlastet 18.08.2015).

9. Willumsen E. Tverrprofesjonelt samarbeid i praksis og utdanning i helse- og sosialsektoren. I: Willumsen E (red.). Tverrprofesjonelt samarbeid i praksis og utdanning. Oslo: Universitetsforlaget. 2009, s. 21.

10. Kjeken I, Sand-Svarterud AL. The Canadian Occupational Performance Measure brukt i rehabilitering. Ergoterapeuten 2012;1:11-18.

11. Willumsen E, Sirnes T, Ødegård A. Nye samarbeidsformer - et samfunnsoppdrag. I: Willumsen E, Ødegård A (red.). Tverrprofesjonelt samarbeid - et samfunnsoppdrag. Oslo. Universitetsforlaget. 2014, s. 19. 
12. Kvilhaugsvik B, Birkeland G. Heimebasert

rehabilitering. Evalueringsrapport. FOUSAM-rapport

2014/1. Tilgjengelig fra:

http://www.helsetorgmodellen.net/wp-

content/uploads/2014/05/rehabiliteringsrapport_2014.1.pdf.

(Nedlastet 19.10.2015). 